\title{
Effects of Ethionamide and Isoxyl on Mycolic Acid Synthesis in Mycobacterium tuberculosis BCG
}

\author{
By F. G. WINDER, P. B. COLLINS AND DOLORES WHELAN \\ Department of Biochemistry, Trinity College, Dublin 2, Ireland
}

\section{(Accepted for publication II May I97I)}

Recent investigations have indicated that the primary site of action of isoniazid (isonicotinic acid hydrazide) is related to the biosynthetic pathway to the mycolic acids (Brennan, Rooney \& Winder, 1970; Winder \& Collins, 1970; Winder \& Rooney, 1970). This note reports investigations into whether any of several other antituberculosis drugs have an action similar to that of isoniazid.

The drugs tested were: Isoxyl (4,4'-diisoamyloxythiocarbanilide), ethionamide ( $\alpha$-ethylisonicotinylthioamide), ethambutol ((+)-2,2-ethylenediimino-di-I-butanol), PAS ( $p$-aminosalicylic acid) and streptomycin. The minimal concentrations of these drugs necessary to give 90 to $100 \%$ inhibition of growth over a period of $48 \mathrm{~h}$. under the conditions of the experiments were determined by measurement of change in dry weight of bacteria over this period. Mycobaterium tuberculosis var. bovis strain BCG was grown in a glutamate-glycerol medium (Winder \& Collins, 1970) with shaking for about Io days, $2 \mu \mathrm{Ci}$ of $\left[\mathrm{U}-{ }^{14} \mathrm{C}\right]$ glycerol of high specific activity was added to each flask, and each drug was added at its minimal inhibitory concentration to a group of flasks, other flasks serving as controls. After $6 \mathrm{~h}$. the bacteria were harvested by filtration, rapidly washed with water, freeze-dried and an equal weight of each set of bacteria taken for fractionation. Free lipids were extracted, the bacteria were saponified, the saponified material was acidified, lipids (bound lipids) were extracted with ether and mycolic acids were precipitated from this extract with methanol. The free lipids, bound mycolic acids and bound lipids other than mycolic acid were dried, weighed and samples were taken for scintillation counting. The residue of material after saponification and extraction was also counted. Details of these procedures have been given by Winder \& Collins (1970).

Initial experiments of this type provided no evidence that either streptomycin or PAS had any appreciable effect on the synthesis of mycolic acids in the experimental period, as might be expected from what is known of the mechanism of action of these drugs on Mycobacterium tuberculosis (Winder, 1964). Consequently, the remaining three drugs were selected for further experiments (Table I). These showed that Isoxyl and ethionamide quite markedly reduced the synthesis of mycolic acids, while providing no evidence for such an effect in the case of ethambutol.

In the case of Isoxyl, the inhibition of mycolic acid synthesis appeared to be only part of a more general inhibition, shown highly significantly in the case of the residue, with marginal significance in the case of the non-mycolic acid bound lipids, and suggested in the case of the free lipids (Table I).

In the case of ethionamide, the inhibitory effect was largely restricted to the mycolic acid fraction, with a suggestion of an effect on the non-mycolic acid bound lipids. This pattern is like that shown by isoniazid (Winder \& Collins, 1970). In a number of other respects this drug affects Mycobacterium tuberculosis similarly to isoniazid (Rist, 1960; Schaefer, 1960; 
Winder \& Rooney, 1970). These facts suggest that ethionamide, like isoniazid, probably exerts its antibacterial action through inhibition of mycolic acid synthesis. There is no cross-resistance between the two drugs and hence their actions are not identical. For example, they might differ in the means by which they reach the sensitive site.

Thus it appears that three specific antituberculosis agents, isoniazid, ethionamide and Isoxyl, show a marked inhibitory effect on mycolic acid synthesis in BCG, though in the case of Isoxyl more widespread inhibitory effects are shown. No evidence for an effect on mycolic acid synthesis has emerged in the case of streptomycin, PAS or ethambutol.

\section{Table I. Effects of Isoxyl, ethionamide and ethambutol on the incorporation of ${ }^{14} \mathrm{C}$ from $\left[{ }^{14} \mathrm{C}\right]$ glycerol into fractions of Mycobacterium tuberculosis $\mathrm{BCG}$}

\begin{tabular}{|c|c|c|c|}
\hline & & Drug & \\
\hline raction & $\begin{array}{c}\text { Isoxyl } \\
\text { (Io } \mu \mathrm{g} . / \mathrm{ml} .)\end{array}$ & $\begin{array}{l}\text { Ethionamide } \\
(2 \mu \mathrm{g} . / \mathrm{ml} .)\end{array}$ & $\begin{array}{l}\text { Ethambutol } \\
\text { (Io } \mu \mathrm{g} . / \mathrm{ml} \text { ) }\end{array}$ \\
\hline
\end{tabular}

${ }^{14} \mathrm{C}$ in fraction compared with control*

$\begin{array}{llll}\text { Mycolic acid } & 0.399 \pm 0.038(4) & 0.354 \pm 0.033(5) & 0.899 \pm 0.133(5) \\ \begin{array}{l}\text { Non-mycolic acid } \\ \text { bound lipids }\end{array} & 0.639 \pm 0.144(4) & 0.742 \pm 0.130(4) & 1.037 \pm 0.176(4) \\ \begin{array}{l}\text { Free lipids } \\ \text { Residue }\end{array} & 0.758 \pm 0.134(4) & 1 \cdot 175 \pm 0.188(4) & 0.772 \pm 0.068(4) \\ & 0.689 \pm 0.041(5) & 0.960 \pm 0.067(5) & 0.946 \pm 0.081(5)\end{array}$

* The d.p.m./fraction/g. dry wt of treated cells was divided by the corresponding figure for control cells. The results are given as means \pm their standard error with the number of experiments given in parentheses.

We thank Miss Anne Slevin and Miss Mairead Kelly for technical assistance. This work was supported by grants from the National Science Council, Republic of Ireland, and Continental Pharma SA.

\section{REFERENCES}

BrenNan, P. J., Rooney, S. A. \& WindeR, F. G. (1970). The lipids of Mycobacterium tuberculosis BCG: Fractionation, turnover and the effects of isoniazid. Irish Journal of Medical Science 3, 37I-390.

Rist, N. (1960). L'activité antituberculeuse de l'éthionamide. Advances in Tuberculosis Research 1o, 69-126.

SCHAEFER, W. B. (1960). Effect of isoniazid on the dehydrogenase activity of Mycobacterium tuberculosis. Journal of Bacteriology 79, 236-245.

WINDER, F. 1964. The antibacterial action of streptomycin, isoniazid and PAS. In Chemotherapy of Tuberculosis, pp. I I I-149. Edited by V. C. Barry. London: Butterworths.

Winder, F. G. \& Colurns, P. B. (1970). Inhibition by isoniazid of synthesis of mycolic acid in Mycobacterium tuberculosis. Journal of General Microbiology 63, 4I-48.

WinDER, F. G. \& RoONEY, S. A. (1970). The effects of isoniazid on the carbohydrates of Mycobacterium tuberculosis BCG. Biochemical Journal II7, 355-368. 